\title{
Alliances Rebalanced? The Social Meaning of the U.S. Pivot and Allies' Responses in Northeast Asia
}

\author{
Sebastian Harnisch and Gordon Friedrichs
}

Pundits and policymakers have articulated growing concerns about a coming clash between the U.S. and China. In this view, the U.S. Pivot to Asia is a (merely hidden) attempt of the Obama administration to preempt the competition with Beijing through strengthening a formidable web of military alliances and partnerships to frustrate Chinese ambitions. If this interpretation was true, U.S. allies in the region would heed Washington's call to arms, because their military dependence would make them comply. Our role theoretical appraisal of the U.S. Pivot and reactions suggests that the material dynamics of security dilemmas in the region have been exaggerated: both, factions within the U.S. and U.S.' allies, Japan and South Korea, differ considerably in casting China as a military threat while they continue to treat China as an economic partner. Focusing on the social structure of security dilemmas, we examine role taking behavior by U.S. allies in all three dimensions of the Pivot. We find that security dynamics depend as much on the role-taking of U.S. allies, and their respective historical experiences, as on the alleged intentions of the two protagonists. It follows that security cooperation and/ or competition in Asia is what concerned states as role holder make of it.

Key Words: U.S. pivot to Asia, role theory, Japan, South Korea

$\mathrm{M}$ ost scholars of the U.S. rebalancing policy towards Asia agree that intended or not - the policies and rhetoric associated with the "U.S. Pivot to Asia" have appeared threatening to the People's Republic of China (PRC), and will thus trigger an (unwanted) counter response (Jackson 2016; Burgess 2016; Liff and Ikenberry 2014, 58; Friedberg 2011). This interpretation of the

*Sebastian Harnisch(sebastian.harnisch@ipw.uni-heidelberg.de) is professor for International Relations at the Institute of Political Science, Heidelberg University. His research interests include comparative foreign policy analysis and Northeast Asian affairs.

${ }^{* *}$ Gordon Friedrichs(gordon.friedrichs@uni-heidelberg.de) is a Ph.D. candidate at Heidelberg University. His research focuses on U.S. foreign policy and the Asia Pacific region.

This paper was being submitted and accepted in September 2016, before the U.S. presidential elections and government transition in South Korea.

The Korean Journal of International Studies Vol.15, No.1 (April 2017), 1-39 
Pivot emphasizes the role of material power differentials and/or incomplete information between a hegemon and an emerging competing power racing towards tragedy. Proponents of this assumption then present a host of evidence of a "new Chinese assertiveness" that is meant to frustrate U.S. undertakings in Asia and which is deemed to be a major driver for an intensified Sino-U.S. military security dilemma (Silove 2016; McDevitt 2016; Lee 2016).

On this crucial point - the plausibility of a coming conflict between China and the U.S., those who study the strategic interaction between the U.S. and China in military terms (Friedberg 2014; Gertz 2013; Liff 2014), the role of information and trust (Lieberthal and Wang 2012), the theoretical and empirical veracity of the power transition theory's variants on China's rise (Chan 2012; Christensen 2015; Foot and Walter 2011; Friedberg 2005; Hsiung 2015; Kugler 2006; Levy 2008; Mearsheimer 2006; Ross and Feng 2008; Yee 2011), and those who anticipate what a future China may want (Heath 2012; Legro 2007; Johnston 2003; Callahan and Barabantseva 2012; Kang 2008), have reached a remarkable consensus: the rise of China and U.S. response determine the future of their bilateral relationship and Asia almost alone.

In this article, we outline a different theoretical framework for analyzing the interaction between the U.S., China and other states in the Northeast Asian region. Our role theoretical approach differs from the predatory interaction between hegemon and competitor realist scholars foresee, and it also differs from the more benign vision that cultural values - such as in Confucian peace or institutional settings - such as in security communities - as such ameliorate or even undo security dilemmas.

In contrast, our role theoretical argument rests on two social constructivist propositions: first, the social meaning of the rise of China and U.S. rebalancing towards Asia is not determined by the actions and rhetoric of those two states alone. Rather, the roles those two powers play are co-determined by the reactions of several other states, most notably allies, partners and rivals. Past scholarship on emerging security dilemmas in Asia has focused on material capacities and information and how these may (or may not) ameliorate growing uncertainties (Glaser 2010; Lindley 2007; Grieco 2014). Based on this literature, we argue that in security dilemmas, particularly in those where material asymmetries will remain substantial in the foreseeable future, much is determined by social factors, such as the identities and role conceptions of the leading power and its competitor, but also the social structure they inhabit.

The second role theoretical proposition is concerned with the sociality of international structure because roles, as social structures, change over time and depend on the social context, i.e. the groups' expectations towards the role a 
state is supposed to perform. We explore two facets of sociality here: first, we hold that historical experiences influence current role behavior because identities (as foundational elements of roles) preserve a historical self-understanding of an actor vis-à-vis others (Benes and Harnisch 2015; Harnisch et al. 2016; Rozman 2011). We do not believe that states remain historically locked in enduring rivalries or cultural hierarchies forever (Smith 2015), because roles are made and remade constantly by the role holder, even if they remain relatively stable due to societal expectations. This is the reason why we remain skeptical about a Confucian peace under Beijing's tutelage. In contrast, we suggest that most Asian states, and certainly Japan and South Korea, have developed a sovereignty-centered understanding of their nationhood during the Cold War, an identity which is often paired with a keen sense for robust Chinese power practices. Secondly, we hold that roles, and the expectations constituting them, shift considerably, when actors change the group of "significant other states" they take into account when considering their own role. By joining institutions, for example, powerful nations indicate credible commitments and self-binding behavior to some states but the same commitment may be interpreted by other states as a lessening commitment towards them. Power, as a central resource in alliances, then appears to depend upon the scope and credibility of the commitment as well as the intensity and demand by allies and partners. We thus argue that the diffusion of U.S. power through the extension of commitments to various partners in Southeast Asia has reshaped U.S. credibility of U.S. alliance commitments in non-obvious ways because whereas Japan has started to diversify its security partner portfolio in South and Southeast Asia vis-à-vis China, South Korea has sought a closer relationship with China.

But international roles, as bundles of domestic and international expectations, do more than simply diffuse power onto more actors. Because roles are also "promises of expected behavior," non-compliance with these expectations undermines trust in the sincerity of the role holder. If role consistent behavior is based on the role holder's utility only, then the respective kind of trust is weak, i.e. strategic trust, because it is not based on a common identity but the belief in the self-interestedness of the other (Finnemore 2009, 75).

As a consequence, we argue that role-taking by lesser powers in Asia have a high potential to constrain future antagonistic alliance formation by both the

\footnotetext{
${ }^{1}$ Hence our analysis does not only supplement Grieco's earlier findings that Asian nations both draw closer and move away from a rising China (Grieco 2014). We also do find substantial differences between U.S. allies and alliances diversification of these very allies beyond the U.S. - both trends which Grieco's analysis misses to identify.
} 
U.S. and China. We therefore supplement earlier power-based analysis on the consequences of China's rise for the Northeast Asian alliance system (e.g. Grieco 2014) by providing a causal explanation how the social meaning of power - i.e. the historical experience of states and their selection of new "significant others" - determines the foreign policy choices of allies which in turn shape the extent of competing major powers.

In this study, we focus on counter-role taking by two U.S. allies, Japan and the Republic of Korea (ROK), in order to illustrate how the divergent social meaning attached to the U.S. role shapes the U.S. alliance systems' evolution (but see Friedrichs and Harnisch 2016). In the following section, we sketch out the role theoretical argument, identify how roles and identities are connected, and show how historical self-identifications inform current role-taking and making. We then apply role theory to the U.S.' role taking and the counter-role taking by its allies.

\section{ROLE THEORY, IDENTITIES AND HISTORICAL SELF-IDENTIFICATION}

International roles are constitutive components of international social structures. They are defined as social positions constituted by ego and alter expectations regarding the purpose of an actor in an organized group (Thies 2010a, 6336). By their nature, they are social, relational and emerging phenomena. So international systems characterized by material unipolarity may differ dramatically from each other, depending on the social purpose of the leadership role by the unipole and the degree of acceptance of that purpose, i.e. legitimacy of the leadership, by dependent or allied states. In a role theoretical perspective, leadership roles cannot be declared unilaterally (and implemented through brute force) for a long time. Leadership roles - as any other role type, have to be "confirmed" by commensurate role taking by others to stabilize social structure, being it institutions, rivalries or friendship.

In the first generation role theoretical scholarship the sociality of a role was low. Studies concentrated on "national role conceptions," i.e. societal expectations and national decision-makers interpretation of it (Holsti 1970; Wish 1980; Walker 1987). In this reading, national role conceptions come close, but are not synonyms, for foreign policy identities. ${ }^{2}$ Depending on the regime type, these national role conceptions are more or less contested, thereby

\footnotetext{
${ }^{2}$ For a recent analysis of South Korea's national role conception, see Hermanns (2013).
} 
influencing the degree to which role conceptions are implemented (Cantir and Kaarbo 2016). A second generation of role scholarship stresses the sociality of roles, i.e. their emergence from ego- and alter-expectations, which strongly shapes the direction, credibility and legitimacy of international roles. In this view, the interaction between domestic and international expectations is a primary source of foreign policy and international social structural change. It follows that more capable countries with a strong domestic consensus may be more able to impose their own role conception and may even uphold it against sustained international contestation. But contestation, deference or support by others determines the nature of the emerging international social order, i.e. the power an actor holds, the purpose and the acceptance thereof by others. Role conflicts, i.e. domestic contestations of ego expectations or external contestations about alter expectations, are thus the prevalent mechanisms of foreign policy change and shifts in the international social structure (Harnisch 2012).

In this article, we explore two social mechanisms that shape role-taking processes and contribute to role conflicts. The first involves the historicity of roles. To assure domestic legitimacy (and prevent contestation), ego expectations about a country's current position must take into account the country's historical experience. Ego expectations must recognize these historical roles (or "historical selfs") because a country's self-conception is built upon an unbroken national narrative to preserve what has been called "ontological security" (Mitzen 2006). Of course, historical experiences can be negative and positive and, over time, they may shift from negative to more positive historical self-identifications as in the German case, or from positive to more negative self-identifications as in Russia's current anxiety vis-à-vis the West. But the historicity of a role is more than a mere instrument of one country or its elite's history to legitimize its current actions because the respective role-taking is dependent upon the commensurate role-taking by others.

The second mechanism involves the "significance of others" for role-taking. In today's international social structure, alliance institutions stabilize alter expectations through long-term legally binding role commitments. Alliances involving great powers are regularly tailored to balance asymmetric material capacities and diverging threat perceptions. But these legal structures are far from self-executing and the respective stabilization of expectations rests upon the commitment and trust between their members. Hence, contemporary shifts in the Chinese military alliance with North Korea - the latter set to establish a credible autonomous nuclear deterrence force - and the U.S. bilateral alliance structure - which is complemented by highly flexible, more short-term security arrangements in Southeast Asia, contribute to the diffusion of social power and 
purpose of the existing U.S. leadership role in Asia.

Against this background, we surmise that the changing expectations towards China - as based on its rapid material economic development, strong territorial claims and robust military modernization - have changed the distribution of expectations towards the U.S. but also other countries, i.e. Russia, India, and Japan, in Asia. We hold that some states, which cast the U.S. economically and militarily into a role of a protector against Chinese influence, tilt the social meaning of the Pivot towards an antagonistic social structure. In turn, we argue that states which cast China into the role of an economic partner or leader while treating the U.S. as a protector of their security interests (even vis-à-vis China) do set in motion a different understanding of the security dilemma in Asia, mixing strategic cooperation and competition. Moreover, those states, which cast the U.S. economically and militarily into a role of a collaborator with China, e.g. by insisting on cooperative economic schemes including China, shift the meaning of the Pivot towards an institutionalist interpretation of the social structure (Zhang 2014).

\section{ROLE-TAKING AND THE U.S. PIVOT TO ASIA}

The U.S. Pivot to Asia - which was later relabeled as "rebalancing" - represented the claim of a reinvigorated U.S. leadership role that rested on the acceptance and active support of regional allies and partners (Meijer 2015; Tow and Stuart 2015; Castro 2013; Clinton 2010). In November 2011, President Obama proclaimed that "the United States will play a larger and long-term role in shaping this region and its future, by upholding core principles and in close partnership with our allies and friends" (White House 2011). The Pivot thus deviated significantly from the antagonistic approach of the George W. Bush administration which the Obama administration deemed too simplistic and wrong (Huang 2016). For the Obama administration, the Pivot first and foremost aimed to reposition the U.S. role from its military entanglements in the Middle East towards the pivotal dynamic Asia-Pacific region and in doing so by focusing equally on diplomatic, security, and economic policy issues.

\section{DIPLOMATIC ROLE-TAKING}

In the diplomatic realm, the U.S. took the role of a mediator to ensure that "international law and norms be respected, that commerce and freedom of navigation are not impeded, that emerging powers build trust with their neighbors, and that disagreements are resolved peacefully without threats of 
coercion" (Castro 2016, 133; White House 2016a). With its first-time attendance of a U.S. administration at the East Asia Summit (EAS) in 2009, the Obama administration displayed more willingness than its predecessors to tie U.S. power in multilateral fora. In doing so, Washington reassured smaller Asian states by allowing them to engage with the U.S. in a symmetrical group context (Tan 2015; Manyin et al. 2012). More specifically, through signing the Treaty of Amity and Cooperation (TAC) with ASEAN, the Obama administration signaled that the preeminent power in world politics was not only bound by principles such as mutual respect for independence, state sovereignty, territorial integrity and non-interference, but that the U.S. was also prepared to make sure that these were respected, e.g. with regard to conflicting parties in the South-China Sea disputes (Acharya 2011; Feigenbaum and Manning 2009). To be sure, the Obama administration favored a 'neutral' interpretation of U.S. mediator role which positioned U.S. leadership as part of a more integrative maritime security structure in the South China Sea. This became visible in 2012, when the U.S. mediated between China and the Philippines on the issue of the Scarborough reef but later hesitated to sanction the PRC for its noncompliance to withdraw naval forces (Spegele 2011). In addition, while Secretary of Defense Carter stated that China's territorial claims are not in line with regional norms, this interpretation of the U.S. mediator role has prevented Washington from taken any diplomatic confrontational stance toward China. Instead, the Obama administration sought to promote a peaceful solution to all islet disputes under the framework of international law (Carter 2015; Department of State 2013). Washington was careful not to include any position on Chinese maritime territorial claims in the so-called ASEAN Sunnylands Declaration of 2016 (White House 2016b). In the wake of the recent UNCLOS ruling on the Scarborough reef arbitration case, the Obama administration had also taken some efforts to ease China's resentment, particularly in the light of the impending G2O and East Asia Summit in September 2016. Washington thereby tried to convince Beijing to pursue accommodation on navigational access, fishing rights, and other sources of disputes with rival claimants. In contrast, a majority of U.S.' allies had expressed their support of the ruling, asking Washington to take on a more robust role and actively penalize Beijing for its behavior (Asia Maritime Transparency Initiative 2016).

To substantiate its role as a mediator, Washington also managed its bilateral relationships with Tokyo and Seoul more pro-actively, e.g. by institutionalizing the ministerial trialogue since 2012 and by coordinating the allies' response to the growing North Korean nuclear arsenal. In doing so, the administration had reiterated its alliance commitments to protect South Korea's and Japan's 
sovereignty against North Korean provocations but it walked a very thin diplomatic line when reassuring Japan in its conflict over the Senkaku islands with China. Here, Washington restated its position that territories under Japanese administrative control are protected under the Mutual Defense Treaty but the Obama administration also took deliberate steps to de-escalate the conflict, e.g. by engaging both parties over the management of the newly established Chinese Air Defense Identification Zone (ADIZ). As one consequence, Japan's Prime Minister made a symbolic visit to the Yasakuni Shrine in 2014 to demonstrate Japan's honoring of its World War II dead, a gesture that aimed to demonstrate strength but also ignited disgruntlement among South Korean officials. In return, under the Pivot, the Obama administration had been keen to settle historic quarrels between both parties by arguing that shared security interests (vis-à-vis China but also North Korea) and democratic values must overcome disputes over the past. The administration's role-taking became evident when Vice President Biden attempted to mediate a Park-Abe meeting in December 2013 as well as in superseding trilateral meetings brokered by President Obama, e.g. on the sidelines of the Nuclear Security Summit in The Hague in March 2014 or in Washington in 2016 (White House 2016c).

\section{SECURITY ROLE-TAKING}

Domestic contestation by Republican majorities in both houses of Congress strongly colored the Obama administration's pitch for the role as a regional protector under the Pivot (Tow 2013). In the Defense Strategic Guidance of 2012, the White House and the Department of Defense (DoD) sought to shift the center of gravity of U.S. forces deployed worldwide to the Asia-Pacific and to prune and reshape the U.S. military posture in the region in order to gain geographic power projection capacity and more operational flexibility (Department of Defense 2012; Deni, 2015). But Congress, under the National Defense Authorization Act, repeatedly neglected the administration's request to close the base in Okinawa and to realign U.S. military presence to the island of Guam, thereby seriously tinkering with ongoing burden sharing negotiations and undermining the administration's reputation as a reliable partner (Envall and Ng 2015).

In essence, congressional role contestation meant that the administration had to lean onto others, i.e. to sway allies and partners to do more for what the U.S. is doing less (Rice 2013). But failure to conform with the norms and values of the U.S. leadership when implementing that role had been potentially dangerous for the success of the Pivot, because it raised questions about the authenticity of the motives claimed, thereby revealing information about the "identity" underlying 
the U.S. leadership role.

To ease doubts about the sustainability and reliability of the U.S. security role, the administration tried to strengthen its alliance networks in the region. More specifically, the administration boosted its navy assets in the Asia-Pacific through the reallocation of $60 \%$ of all maritime assets by 2020 , including six aircraft carrier groups and a majority of the navy's cruisers, destroyers, and littoral ships. Also, the DoD intended to accelerate rotational air force and army deployments by providing more military equipment and assets to allies and partners in the region (Castro 2013). ${ }^{3}$ But several budget reductions seriously circumscribed the Pentagon's capacity to revamp U.S. military posture: overall troop numbers in the army are down to 420,000 under the Force Structure Review until 2019; also, the readiness of flying units had been reduced combined with a 30 percent cut in operations of navy ships and aircraft (Jensen and Shibuya 2015, 95; Wood 2015; McLeary and Peniston 2014; Chadha 2014).

Recognizing the need for a better presence in the region, the U.S. also formed several additional bilateral strategic partnerships and conducted more joint military exercises with allies and partners in the region, such as the Rim of the Pacific Exercise in 2014 (Parameswaran 2014; Paul 2015, 27). At the same time, however, overall American security assistance to allies and partners had decreased since the Pivot's announcement (Council on Foreign Relations 2016). This was not all the administration's fault, as the DoD had to allocate considerable resources to the Middle East for the war against the Islamic State in 2016 ( $\$ 8.8$ billion in total; White House 2015a). But when you compare these allocations to the $\$ 425$ million "New Maritime Security Initiative" for the Asia Pacific announced in 2015 - which aimed to build up ally and partner maritime capabilities to address a range of challenges, i.e. the South China Sea, through improving regional maritime domain awareness, expanding exercises, and leveraging senior-level engagements - it becomes clear why some allies and partners started to question the seriousness of U.S. commitment to the Pivot (White House 2015b; Mehta 2015).

The social meaning of shifts in material assets had become particularly clear in the implementation of the U.S. Air-Sea-Battle (ASB) concept (also known as "Joint Concept for Access and Maneuver in the Global Commons"). The ASB has been interpreted in the region and beyond as a protective belt for American allies and partners against China's anti-access and area-denial (A2/ AD) strategy in the East and South China Sea (Department of Defense 2013;

\footnotetext{
${ }^{3}$ Korea in 2015, two littoral ships to Singapore by 2016 (two additional by 2018), and troop deployments on a rotational training basis to Darwin, Australia in 2011.
} 
Paul 2015). But strong U.S. demands for military inter-operability under the ASB concept, such as operating weapon systems, information exchange and the coordination of land and sea based ballistic missile systems, raised questions and nurtured uncertainty among allies and partners because of the impact these demands may have on the respective national arms industrial bases (Dian 2015). In addition, because the ASB concept triggered substantial skepticism among Chinese decision makers, some allies worried that deeper integration with the U.S. means stronger alienation of China. In the case of South Korea, these consideration led to considerable "Seoul searching" over plans to deploy the Theater High-Altitude Area Defense (THAAD) which is meant as a reassurance but is increasingly perceived as a potential for entrapment and/or bears the potential to be interpreted by Chinese officials as a deterrent (Swaine 2012, 6). Although the DoD emphasized the defensive nature of THAAD - a ballistic missile defense system (BMD) targeting to intercept North Korean missiles Congress expressed support for funding regional BMD capabilities of allies as a protective measure against Chinese assertiveness (i.e. PAC- 3 batteries stationed in Taiwan and Japan), thereby further pressing Seoul's alignment policies with Washington (Rinehart et al. 2015). Long-term plans by the DoD to reposition the remaining 28,00o U.S. troops from the Korean Demilitarized Zone (DMZ) to the south, accompanied by a change in U.S. command structure, spread fears of U.S. abandonment.

In sum, under the Obama administration the U.S. took on the role of a constrained regional protector. The administration's role conception was hampered by congressional contestation through budget cuts and gridlock concerning the revision of the conventional deterrence defense posture. Given this ambivalence, regional allies and partners started to define their own security role more independently, particularly Japan, South Korea and Taiwan, who repositioned themselves either closer or further apart vis-à-vis China and other threats (Futter and Zala 2015).

\section{ECONOMIC ROLE-TAKING}

In the economic realm, the Obama administration took on the role of a regional trade liberalizer by promoting the multilateral Trans-Pacific Partnership (TPP) (Lim et al. 2012; de Rougé 2015). ${ }^{4}$ In doing so, the U.S. demanded substantial reforms of domestic economic regimes by prospective member states,

\footnotetext{
4 With a total population of more than 2.2 billion people, the members of the TPP combine a GDP of U.S. \$24.5 trillion in 2012, representing some 29\% of global GDP and an extensive market which accounts for $28 \%$ of U.S. goods and services exports.
} 
particularly in the area of special and differentiated treatments and state-owned enterprises (a major challenge for states like Vietnam, Singapore and Malaysia). In turn, TPP opened up the possibility for developing states to "lock in" domestically contested political reforms, stabilizing their own commitment to an open market economy and improving their attractiveness for foreign investment (de Rougé 2015, 111).

By establishing TPP, the Obama administration also committed and bound the U.S. to a host of agreements on environmental goods' tariff reductions, energy security, food security and sustainable agriculture, fostering supply chains, as well as lowering technical barriers for trade facilitation (Martin 2012). But again, domestic contestation stirred uncertainty about the U.S.' sustained willingness to not only negotiate but also ratify a long-term trade agreement (Hornbeck 2010; Fergusson et al. 2015). After the TPP signing ceremony in February 2016 in New Zealand, conflict between the Republican led Congress and the White House had remained prevalent, focusing on intellectual property rights and the issue of currency manipulations by some Asian states (Ferguson et al. 2015; Schneider 2013). As a result, many U.S. legislators, including both presidential front-runners in the 2016 U.S. presidential elections, announced to block TPP in its current form (Ikenson 2015). In turn, the American ambivalence spread and sparked domestic contestation within other TPP member countries (Tow 2013, 21). With six of the 12 signatory countries holding national elections in 2015/2016, overall implementation of TPP either could had been delayed for up to 2 years if only half of the member states managed ratification, or the whole agreement may had been derailed in the end. ${ }^{5}$ Moreover, by excluding major economies such as China, Indonesia, the Philippines, and South Korea thus far - all of which have substantial exchanges in goods and services with the U.S. TPP beard the potential to drive a wedge between APEC member states (Green and Goodman 2016).

As a result, TPP had also been partially overshadowed by both intra-regional and China-led regional trading schemes. On the one hand, other APEC members pushed for alternative regional integration models such as the ASEAN +3 and the ASEAN+6, to facilitate a Free Trade Area for the Asia-Pacific (Martin 2012). On the other hand, the China-led Regional Comprehensive Economic Partnership (RCEP) scheme, but also the Asian Infrastructure Investment Bank (AIIB) under the Chinese "One Belt One Road" initiative, has found strong followership: Excluding the U.S., RCEP encompasses all ASEAN+3 states as well as India, Australia, and New Zealand (de Rougé 2015). In contrast to TPP,

\footnotetext{
${ }^{5}$ The U.S., Chile, Peru, Vietnam, Thailand, and Malaysia.
} 
RCEP allows for "numerous flexibility caveats ensure that no member has to adopt trade policies with which it disagrees, and it protects sensitive industries from exposure to enhanced competition (Kawai and Wignaraja 2010; Ye 2015; Murray and Hanlon 2012).

Below the multilateral trade agreements' surface, the administration has initiated several bilateral negotiations and investment treaties such as the U.S.South Korea FTA (KORUS) or the U.S.-Japan FTA (de Rougé 2015, 113-114). Moreover, the U.S. established some bilateral accords, including National Export Initiative to lower the impact of certain countries' trade deficits with the PRC, and to counter China's trilateral efforts, such as the proposed China-JapanROK FTA. Overall, these initiatives beard some potential to initiate an economic rivalry in the Asia Pacific (Ilias et al. 2011; Azizian 2012).

In sum, the Obama administration's economic role as an initiator and mediator, promoting both multilateral and bilateral economic cooperation, came under sustained domestic contestation. This U.S role-taking, in turn, sparked insecurities among regional states whether and how to choose between competing economic power houses.

\section{COUNTER-ROLE TAKING}

"In a span of two decades, successive reinterpretations of history in Japan, South Korea and China have alarmed neighbors and posed an unexpected challenge to U.S. thinking” (Rozman 2011, 2).

The purpose of this section is to sketch out counter-role taking by two U.S. allies, Japan and the ROK, in order to illustrate how the divergent social meaning attached to the U.S. Pivot shaped the U.S. alliance systems' evolution. We focus on two democratic regimes - Japan and South Korea -that share close - partly controversial - relations with the PRC and the U.S., but differ in their respective historic experiences and regional socialization. We examine how and to what effect historical self-identification informed their response to the U.S. Pivot and their role-taking towards the PRC. 


\section{JAPAN: A WELCOME RETURN AND A NEW U.S.-JAPAN MILITARY POSTURE}

\section{DIPLOMATIC COUNTER-ROLE TAKING}

In the diplomatic pillar of the Pivot, Prime Minister Abe invested an unprecedented amount of time, effort and personal commitment to diversify and strengthen Japan's diplomatic (and security) relations. In the first 15 months in office, the Prime Minister alone visited 49 countries (Sakaki 2015, 33). Japan's advances in its relations with Australia and India received a lot of media attention but one could argue that the Abe government specifically targeted Southeast Asian countries: After taking office, Abe first visited Vietnam, one of the main protagonists in the dispute over the South China Sea, in January 2013. In February 2013, Japanese officials travelled to Manila to discuss maritime security cooperation which subsequently led to the provision of ten patrol vessels to the Philippine Coast guard (Le Mière 2013, 35).

But Japan's diplomatic role-taking has been shaped by domestic considerations, thereby shifting it away from a loyal ally or regional leadership role commensurate with the U.S. Pivot. Under Prime Minister Abe, the Japanese government has started to consistently employ nationalistic rhetoric and positions when it comes to Japanese war crimes during the Pacific war, including several high-profile visits of the Prime Minister himself to the Yasukuni Shrine (Maslow 2016). As a consequence, Japan's traditional dominant discourse, which had casted China and Korea as victims of Japan's aggression, has been challenged by a much more ego-centered historical narrative in which Japan is displayed as a victim of external bullying (Suzuki 2015). In this reading significant 'Others,' in particular China, deny Japan's (now) peaceful identity due respect, thereby undermining Japan's reassertion as a powerful nation (Hagström and Gustafson 2015, 9).

Japan's new historical self-identification under Prime Minister Abe has led to a situation in which Tokyo has intensified diplomatic relations and held important summit meetings with a great number of countries in the near and far abroad. With its two most important and immediate neighbors, South Korea and China, however, relations remained tense or deteriorated over conflicting historical interpretations and disputed territories during the same period (Green $2013,8)$. In the case of South Korea, bi- and trilateral defense and intelligence cooperation, which had been a long-term goal of the U.S., has suffered from continued disagreements and nationalistic furor on both sides (Le Mierè 2013, 38; Delury 2015). In the case of China, Abe's admission of Japanese war crimes during the 70th anniversary of the end of the Pacific War 2015 resulted 
in the nations' first bilateral security dialogue and the so-called "four-pointplan," which acknowledged disagreement over the legal status of the Diaoyu/ Senkaku islets while stressing a series of bilateral concerns and common strategic interests (Ministry of Foreign Affairs 2014). Yet, Abe's statement at a joint session of the U.S. Congress in 2015 was seen as a stimulation of deep Chinese resentment against imperial Japan, which was seen as beneficial to the following-up China-Japan-South Korea trilateral summit the same year, the first since 2012 (Smith and McClean 2015). The recent settlement of the Comfort Women issue between Japan and South Korea further strengthened both countries role commensurability, and fostered bilateral engagement with either of the great powers in terms of security (i.e. on the North Korea and South China Sea issue) and economy (i.e. free trade negotiations). At the same time however, Japan's more assertive diplomatic role-taking from time to time aggravates inter-Korean relations, as could be witnessed after Tokyo's new round of unilateral sanctions in the aftermath of recent provocations by North Korea. Given these developments of Japan's diplomatic positioning towards significant others, Tokyo has, over the years, taken the role of a matured balancer (Manicom 2014).

\section{SECURITY COUNTER-ROLE TAKING}

The U.S. announcement of the Pivot substantially reshaped Japan's security policy role. Central to the strong resonance by Japan was the U.S.' alliance diversification, in which pre-existing alliances are reshaped and trilateralized to encourage synergies and new partnerships are developed, reshaping the force posture (through forward distribution and storage) to address symmetrical challenges in marine-based theaters rather than land-based asymmetrical threats (Van Tol and Krepinevich 2011; Dormandy 2012).

Most important are the new National Defense Program Guidelines (NDPG) of 2013 which substantially expand the concept of "dynamic deterrence" (dohteki boei ryoku) into a "strategy of pro-active pacifism" (Ministry of Defense 2013; Armitage and Nye 2012; Green and Szechenyi 2014). Besides introducing a National Security Council in 2012, the Abe administration also successfully implemented new Bilateral Security Cooperation Guidelines in April 2015, a fundamental element in the division of labor in the U.S.-Japanese military alliance (Klingner 2016). In combination, these two measures entail the deepening of defense capacities and military interoperability with Washington; an expansion of bilateral and multilateral cooperation with regional partners (i.e. South Korea and India); a proactive role within regional and global security cooperation; as well as the reformation of institutions for the purpose of 
deterrence and crises management (Ministry of Defense 2013, 11).

In a related move, the Abe administration has successfully tweaked the Japanese constitution in its favor. The 70-year-old prohibition to deploy the JSDF abroad (Article 9) has been upended (Liff 2015). Japanese forces may now provide logistical support to foreign militaries or even defend U.S. and other "friendly" forces against an armed attack (Hosoya 2016; Shorrock 2015; Lee 2015). The JSDF redirects its own posture, in close cooperation with the U.S. ASB concept, to focus on regional deterrence at sea (esp. anti-submarine warfare), patrolling and regaining control of the waters of the Sea of Japan and East China Sea (Dian 2015, 9; Jimbo 2015, 80).

Recent constitutional reforms have also facilitated the broadening of Japan's geopolitical focus, even beyond the Asian continent toward the Eurasian littoral and maritime areas, to capture economic and political opportunities without the historical controversies it faces in East Asia (Nakanishi 2015). In this vein, the Obama administration welcomed a Japanese extension of air patrols into the South China Sea which supplements Japan's various efforts to deepen its military ties with ASEAN countries, including military exchanges, training and defense technology and equipment support (Sakaki 2015). Development aid is used strategically by the Abe administration to strengthen the regional defense posture of ASEAN states, i.e. including measures by the Japanese Ministry of Defense to strengthen sub-regional humanitarian assistance capacities, disaster preparedness and anti-piracy. In doing so, these measures signaled a Japanese interpretation of the U.S. Pivot as a counter-balancing effort against China (Nakano 2015; Yamaguchi 2016; Jimbo 2015, 86).

The distinct pattern of Japanese commensurate role-taking clearly shows that indigenous factors, such as the Abe government's conservative and nationalist sentiment, do explain Japan's shifting role trajectory (Saltzman 2015). In some areas, one could even argue that the Obama administration urged Japan to take a less confrontational stance vis-à-vis China and Korea, e.g. facilitating a Japan-Korean summit meeting or urging Japan to engage China diplomatically on the Diaoyu/Senkaku island dispute. Regarding the latter, U.S. accession to the TAC has been interpreted by Japan as an attempt to position the US as a dispute settler in Southeast Asia (Manyin et al. 2009). Not surprisingly, the Abe government expressed its support of the U.S. FONOPs in 2015 and even announced that a Maritime Self Defense Force escort vessel will proceed with a U.S. carrier in the near future (Chapman 2016).

In nuce, Japan has taken on a much more robust and pro-active regional balancer role vis-à-vis China in the U.S.-Japan alliance, substantially expanding Japan's geographical and functional security perimeter (Capistrano and 
Kurizaki 2016). This new role is informed by a reevaluation of Japan's historical perpetrator role and an increasing realization that Japan has lost some of its privileged relationship with Washington. To compensate for this loss and bolster its own defense policy options in the face of a declining economy, the Abe government has sought new partners and relationships to hedge against an emerging Chinese territorial threat (Hoey 2016; Le Mierè 2013; Singh 2015).

\section{ECONOMIC COUNTER-ROLE TAKING}

Changes in the U.S.-Japan security alliance have not been matched by a similar intensification of Japan's commercial ties with the U.S. or the region as a whole. Following Green's (2013) interpretation of Abenomics and Japan's trade policy posture, the Japanese contribution to the economic Pivot suffered from two inter-locking role-taking processes: On the one hand, ongoing quarrels between the Obama administration and congressional leaders made it unclear if and when negotiations and subsequent compromises will find the necessary ratification majority in Congress. On the other hand, the Abe government faced substantial domestic opposition to TPP on its own. These interest groups vehemently contest the beneficial effects of any further market openings in several key areas, thereby blocking critical compromises (Green 2013, 4). As a reaction and similar to Japan's military role-taking efforts, the Abe administration has framed TPP as an important agreement that supports Japan's security and geopolitical role as a regional stabilizer, arguing that under TPP it can leverage the agreement's size and scope to limit or at least condition China's overall trade influence in the region (Mulgan 2016).

Yet at this time, Japan takes on the role of a troubled economic reformer in some key areas (agriculture) which, in turn, blocks any substantial Japanese regional leadership role-taking. Domestic resistance hampering multilateral and bilateral trade negotiations, such as a Japan-Australia Economic Partnership Agreement, is the most important factor explaining why Japan's commensurate functional role-taking to the U.S. Pivot had been so unbalanced. But there are a few exceptions to Japan's role as a troubled economic reformer. On the one hand, recent changes in Japan's strict arms export policy guidelines have opened up the spectrum of a potential boost in defense-related commercial gains (Keck 2015). In turn, these reforms could set in motion an overhaul of Japan's cartelized and underperforming defense industry, which has long been based on a "policy of kokusanka" (internalization and indigenous production). On the other hand, Japan's strategic interest in developing a much closer and sustainable cooperation with India, has led to a substantial intensification of bilateral commercial relations. Based on the 2006 Strategic Cooperation 
agreement, both sides have concluded a Comprehensive Economic Partnership Agreement in 2011, which for example gradually lowers the tariffs imposed on some 90,000 goods and accords "national treatment" to each other's investors (Khan 2014).

Returning to the question of historicity and sociality in the Japanese interpretation of the Pivot, it is fair to say that Prime Minister Abe's conservative reevaluation of Japan's past has been a key legitimization of its robust positioning vis-à-vis China. By securitizing the U.S. Pivot, Japan through its role-taking has cast China (and North Korea) into the role of the 'Other,' thereby contributing to a more competitive if not hostile interpretation of the anarchy in East Asia (Smith 2015). In addition, while Tokyo welcomed the Obama administration's focus on the dynamic Asian region, it worried that the U.S.' diversification of partners and repositioning of attention did weaken its commitment to the security of Japan, particularly to those areas under Japanese administrative control. Tokyo subsequently intensified its security cooperation with Washington but also diversified its role-taking in the region so as to limit the dependency on Washington. Exposure to a diverse set of expectations from the U.S. across the pillars of the Pivot therefore set in motion a change in Japanese role behavior in which Japan had relied on diplomacy to diversify its partnerships, especially in South and Southeast Asia, utilized the security alliance to hedge against China, and remained ambivalent about a deeper integration into TPP because of the simultaneity of domestic concerns and security considerations.

\section{SOUTH KOREA: \\ TRUSTPOLITIK AND MIDDLE POWER ASPIRATIONS}

\section{DIPLOMATIC COUNTER-ROLE TAKING}

Diplomatically, the U.S. Pivot had been framed as a welcome gesture among the ruling conservative New Frontier Party (NFP) and the then President Park Geunhye because they believed that a positioning of the U.S. leadership complements South Korean role-taking vis-à-vis North Korea and other regional powers (Kim 2015a, 92). Korea's traumatization as a Japanese colony was important for shedding its identity as a "client state" under China's tutelage (Hwang 2003), but after liberation from Japanese rule (which Koreans call the "restoration of light”), South Korea's nationalistic movement fell into an uneasy acceptance of the division of the country, trying to use North Korean provocations to unify the two entities under South Korean rule. These debates stimulated voices which 
are more skeptical of South Korea's dependency on U.S. security guarantees and which support a more open stance vis-à-vis China (Chung 2007).

To cut across historical cleavages that fuel much of South Korea's contemporary domestic contestation between progressive and conservative groups, the Park administration proposed a "Trustpolitik" (Park 2011, 129). It sought to align South Korea's security to a closer rapprochement with the North through opening an inter-Korean dialogue and by engaging more constructively with Beijing and Tokyo (Park 2011, 17; Manyin et al. 2015, 11). Yet while Park was ambitious to propose the groundwork for unification through economic exchanges and humanitarian aid (including family reunion), Trustpolitik was not met with commensurable counter-role taking by Pyongyang, which itself, under the new Kim Jong-Un leadership, promotes independent unification (an interpretation of a communist-led unification), criticizing Trustpolitik as a plot to instigate regime change in the North.

Park's Trustpolitik also reshaped U.S.-South Korean relations. In 2015, Seoul and Washington held their first " $2+2$ " meeting since 2010, including both Secretaries of State and Defense to discuss issues such as cybersecurity, space, missile defense and others. Supplemented by defense ministerial meetings and a Nuclear Security Summit meeting in Seoul, these efforts aimed to strengthen the U.S.-South Korea deterrent posture, even when paired with cooperative efforts to dismantle the North's nuclear program. The opposition, the progressive New Politics Alliance for Democracy (NPAD), repeatedly criticized Park's new diplomatic role-taking, complaining that it offered too many concessions to the U.S. and antagonized China. Challenging this domestic contestation, the Park administration aimed to improve relations with both China and Japan through a trilateral summit (including the establishment of a trilateral secretariat in Seoul), and an initial investment agreement to lay the groundwork for trilateral FTA negotiations. The latter was meant to complement President Park's Global Asia initiative, which promoted Asian values as a substitute for the overreliance on the U.S. as a problem solver (O’Neil 2015).

Under President Park's Trustpolitik, Seoul also began to form a Northeast Asian Peace and Cooperation Initiative (NAPCI) to also build trust within the region and solve the paradox of growing economic interdependence and conflictual political-security relations (Sheen 2014). NAPCI had been envisioned by its sponsors as a regional multilateral effort to foster economic growth and security stabilization via cooperation in climate, disaster relief, and cyber -security issues, but the initiative depends on role-taking by North Korea because DPRK behavior potentially triggers diverging Chinese and Japanese responses, thereby undermining a coherent PRC, ROK, and Japanese reaction (Lee 2011). 
Recent provocative role-taking by North Korea, including Pyongyang's fourth and fifth nuclear test followed by ballistic missile tests, caused turbulences for Park's inclusive Trustpolitik, leading to the closing of the Kaesong joint industrial complex and even Park's invoking of the collapse of the North Korean regime at her address to the National Assembly 2016 (Park 2016).

Moreover, instead of embracing NAPCI, the Obama administration put more emphasis on the re-activation of the Six-Party Talks. As a result, Seoul focused on taking a commensurate U.S. counter-role via the EAS (and the TAC more specifically) in order to foster a common set of values within the region. The TAC accession led some experts to question U.S. freedom of action (particularly the TAC's emphasis on non-interference), including potential constraints on its alliance obligations, and thus South Korea conditioned its TAC membership on the premise that accession would not affect any obligations under other bilateral or multilateral agreements (Manyin et al. 2009).

Trustpolitik came under scrutiny after President Park's attendance of the 7oth anniversary of the end of WWII event in Beijing. While reflecting a common historical experience and strong commercial and cultural ties in the recent past, this symbolic attendance was interpreted by many U.S. and Japanese policymakers as a re-positioning of the Republic of Korea towards China and therefore out of tune with their interpretation of the U.S. Pivot towards Asia as a reassurance vis-à-vis China. Korea's historical self-identification as a victim of Japanese aggression also continues to spark much of the domestic concern about Japan's intentions and actions, e.g. the Abe government's initiative to revise Article 9 of the Japanese constitution. For Seoul, the Japanese seizure of the Dokdo islets in 1905 still reflects a "subjugation and humiliation of the nation at the hands of Japan, a trauma that remains vivid to this day" (Selden 2011, 1). Also, Japan's thirty-five years' annexation and the aspired "Japanization" of Korea represents, until today, a substantial potential for Korean resentment and sometimes conflictive behavior towards Japan (Izumi 2001). Historic interpretations of former relations are still very sensitive and stir conflict regularly, e.g. debates on Japanese history school textbooks or repeated visits by Japanese prime ministers to the Yasukuni shrine (Togo 2011, 105). Against this background, the Park administration adopted a two-track approach: on the one hand, it raised concern about Tokyo's dealings with history; on the other hand, Seoul separated the historical issue from other aspects of the relationship, which allowed for the recent settlement of the comfort women issue. Seoul held a bilateral high level state visit in 2015, i.e. the Japan-Korea Future Dialogue (Kang and Bang 2015), and Park responded positively to U.S. diplomatic initiatives to foster trilateral cooperation, such as the U.S.-ROK-Japan trilateral information 
sharing agreement in 2014.

In sum, it appears that South Korea's diplomatic counter-role taking as a constrained trustbuilder implied a limited approach to overcome negative historical self-identifications towards Japan and China for the purpose of establishing a trustworthy multilateralism to deal with an unruly North Korea (Wiegand 2015).

\section{SECURITY COUNTER-ROLE TAKING}

For South Korea's military counter-role taking, historic self-conceptions proved to be equally important. After the Korean War, South Korea received critical assistance from the international community under U.S. leadership which propelled its economic, democratic and political development. However, Korean democratization resulted in a lively public debate of Korea's colonial occupation and U.S.-Korean relations, especially controversies surrounding U.S. wartime actions and the so-called Kwangju massacre.

On balance, a militarized interpretation of the U.S. Pivot put strong pressure on Park's trust-building policy towards Pyongyang and the region in general, thereby limiting Seoul's leeway for an incentive-based position. In turn, North Korean military provocations had met a lukewarm response from Washington because the Obama administration focused on stemming proliferation. In South Korea, however, Pyongyang's exasperations led conservative groups to push hard for a more robust deterrence and closer alliance with the U.S., thereby reiterating historic narratives where North Korea and also Japan are latent threats to South Korean sovereignty (Kim 2015b, 485).

The Park administration took these domestic cues seriously and transformed the U.S.-South Korean military alliance to a proactive deterrence posture. At first sight, the ROK took on a commensurate counter-role that accounts for the shift in the U.S. strategy from a total war scenario to a much more flexible, faster response force. In 2005, Seoul initiated a Defense Reform Plan to make its military smaller and more flexible, reducing its troop strength from 681,000 to 500,000. Seoul also increased the number of its advanced fighters and surveillance aircraft. This posture aimed at a less militarized South Korean society but also a more autonomous force that accounts for the U.S. plans to replace the current command structure OPCON (which, in the case of war, brings South Korean forces under U.S. command) with the much more autonomous command system KORCOM. These reforms also complemented U.S. plans to reposition the remaining 28,00o U.S. troops from the DMZ farther 
south (Kim 2015a, 92). ${ }^{6}$ But conservative critics suggested either that the latter may lead the U.S. to eventually abandon the ROK, or that KORCOM comes with too many financial and other responsibilities attached.

Historical self-identification and regard for China as a "significant other" also shape Seoul's positioning on regional BMDs, i.e. the THAAD. The cleavage runs between those parties and factions that want to pursue a more robust security and defense policy, especially towards North Korea, and those factions which aim at the left-center of the party spectrum. Domestic resistance among left of center political groups is often based on complaints about the U.S. role during military dictatorship and Japanese hesitance to face its past squarely. These and other groups then call for a more autonomous South Korean stance which must not irritate China. In this particular view, the U.S.'ASB concept is presented as an instrument to pressure South Korea's military to participate and deploy its BMD in the region, which threatens to damage the comprehensive strategic partnership with China.

In light of the security deterioration on the Korean peninsula under Kim Jong-Un's rule, the Park administration in early 2016 made a bold move by announcing the deployment of THAAD by the end of the year. In turn, President Park's change in rhetoric vis-à-vis the North had aggravated South KoreaChina relations because Beijing favors a restrained South Korean role within the U.S. alliance system. Moreover, North Korea's escalating provocations and Seoul's subsequent security rapprochement with Washington finally derailed the main pillars of Park's Trustpolitik. Not only did Pyongyang's escalation call into question Park's strategy to use improved bilateral relations with Beijing to pressure the North. Closer Sino-South Korean relations also fueled considerable domestic contestation by conservative groups which still hold historic animosities vis-à-vis China (and North Korea). But Park's alternative strategy, to bolster Seoul's defenses against the DPRK's expanding missile programs was met by sustained domestic opposition against China: on the one hand, local communities fear that THAAD deployment in their region will bring more costs (in sovereignty and security) than benefits (Moon 2013). On the other hand, business groups with close ties to China or investment there believe that a closer alignment with Washington will be penalized by the PRC government. As a consequence, the THAAD system remains controversial not because of technical

\footnotetext{
6 The planned realignment of U.S. forces is based on moving 9,000 troops to the U.S. army Garrison Humphreys base and another relocation of 10,000 troops to areas south of the Han River. This implies that USFK sites will decline to 48, from 104 in 2002. The bulk of U.S. forces will build a hub of Osan Air Base/USAG Humphreys and Daegu, Chinhae Naval Base, and Kunsan Air Base.
} 
questions but because of China's concerns that its radar capacity can be used by the U.S. to monitor Chinese airspace deep into its territory (Manyin et al. 2015; Snyder and Byun 2015).

With diverging role cues from Washington and Beijing cross-cutting each other, such as China's territorial claims in the South China Sea and U.S. alliance requests (Snyder and Byun 2015), South Korea first opted to develop its own BMD system called Korea Air and Missile Defense (KAMD). The KAMD has been deemed as a self-restraining collective defense under which Seoul would have committed itself to a much more limited missile interception capacity. But after several missile tests in the first half of 2016, the Park administration then decided to supplement KAMD by agreeing to immediately deploy advanced THAAD technology by the end of the year (Pollack 2016). While Chinese officials and state-led media openly threatened to severe the close economic and cultural Sino-South Korean ties, threats as these will - after some domestic debate - probably harden the South Korean domestic consensus that China - while claiming a role as a responsible Great Power - has not done enough to reign in the behavior of its only formal ally North Korea(Snyder 2016).

While China's "one belt, one road" initiative and recent North Korean provocations have pushed South Korea into closer alignment with the U.S. and Japan, Seoul's troubled historic experience with Japan still pulls it back from Tokyo. For many policy makers in Seoul, past Japanese misdeeds, the current competition for the small Dokdo/Takeshima islands, and the ongoing economic competition are fused into a potent national narrative that Japan may not be trusted. As Park Jie-Won, leader of the oppositional party in the General Assembly put it: "We should not give away our classified military information to Japan, which intends to go nuclear. People here still have animosity toward Japan's claim on Dokdo" (as quoted by Wiegand 2015, 348). Such animosities resulted in action detrimental to Washington's strategy to foster dialogue, e.g. in 2015, the General Security of Military Information Agreement and the Military Acquisition and Cross-Servicing Agreement were cancelled (Wiegand 2015, 348). Since then, however, Seoul and Japan had engaged in some trilateral meetings with U.S. counterparts, underlining the importance of U.S. role-taking for the state of the bilateral relations and the characteristic of Seoul's military role as a contested pacifier.

\section{ECONOMIC COUNTER-ROLE TAKING}

In the economic realm, the U.S. and South Korea play an almost equally important role for each other: South Korea is the U.S. 6th largest trading partner, while the U.S. is South Korea's second-largest trading partner, second- 
largest export market, and third-largest source of imports, as well as the largest supplier of foreign direct investment. It comes as no surprise then that both countries have taken on complementary roles in terms of bilateral free trade. The KORUS FTA (2012) further improved bilateral trade relations leading the ROK to join the preparatory phase of the TPP initiative. However, the Obama administration signaled that outstanding issues from the KORUS FTA had to be addressed first before Seoul could accede to TPP. Washington had thus casted Seoul into the role of a mere trading partner and not a strategic partner to define future global trading standards.

Chinese bilateral and trilateral FTAs (including RCEP) on the other hand, have been interpreted as a counter punch against TPP, forcing South Korea (and Japan) to choose sides or functioning as leverage for the ROK against Washington (de Rougé 2015, 112; Nicolas 2007). As 25 percent of Korean trade is conducted with China and the two countries share a total trade of $\$ 270$ billion (more than the combined total trade with the U.S. and Japan), South Korea's economy is significantly more dependent on the PRC than Japan is. Thus, when in 2012 the ROK joined the RCEP, while the Japanese government was able to overcome powerful domestic opposition to join TPP, it appeared as if Japan and South Korea were indeed taking different sides. This view gained further ground when South Korea joined the Chinese-led AIIB in 2015 and pursued stronger inter-Korean economic cooperation, e.g. the Trans-Korean Railway project. Economic rapprochement finally culminated in June 2015 when South Korea and the PRC concluded a bilateral FTA - which will boost trade to over $\$ 300$ billion a year, up from $\$ 215$ billion - accompanied by the opening of dialogue between their nations' national security councils (Snyder and Byun 2015). Yet in October 2015, President Park stated her support for South Korea joining the U.S.-led TPP initiative despite the fact that Seoul may not be able to shape much of the agenda anymore (Lee 2015). At the same time, several domestic groups have contested South Korea's economic role-taking in the light of the THAAD deployment because they fear economic retaliation by China. In 2014, South Korea earned over $\$ 55$ billion in profits from China, providing Beijing with enough leverage to impede Chinese support and cooperation for inter-Korean relations. The Park administration tried to ease those concerns by joining the AIIB under Chinese leadership. Therefore, in the economic realm, Seoul took the role of an equidistant partner vis-à-vis both great powers by signaling cooperation under the principles of Trustpolitik, avoiding role conflict and disturbance of valued-based regional integration politics.

In sum, we find that South Korea's response to the U.S. Pivot is colored strongly by its historical experiences with all major parties concerned. President 
Park's Trustpolitik represented an ambitious effort to establish trusting bonds by balancing role cues from the U.S., China and Japan in an equidistant positioning as a middle power vis-à-vis Washington and Beijing (Hermanns 2013). Yet it left Seoul also more dependent upon the outcome of significant other's role interaction. Seoul had thus cautiously responded to the military Pivot, despite ongoing North Korean provocations, in order to preserve its autonomy for cooperation towards China. In addition, it distanced itself from Japan's more robust posturing, seeking multilateral initiatives and remained skeptical towards the Abe government's willingness and its intentions to address Japan's historical and territorial disputes squarely. Economically, the Park government reinterpreted the U.S. Pivot by pursuing a policy of equidistance between Beijing and Washington because its wellbeing hinges more upon China's than anybody else's economy. Domestic historical grievances concerning Japan, China and the U.S. do set clear limits for future cooperation with any of these partners while they certainly prevent deeper trilateral military integration to contain China.

\section{CONCLUSION}

The strength of the U.S.' alliance system in Northeast Asia depends as much on the material capacity as on the social purpose the allies agree upon. The U.S., as the world's most powerful nation, can shape - through the Pivot to Asia, as exemplified in this paper - this purpose to some degree, but much depends on the role-taking by Japan and South Korea. We find both converging and diverging patterns of U.S. role and counter-role taking by its allies that shape current and will limit future changes in the social structures of Northeast Asia. We gather that full-blown security dilemma between the U.S. and China is unlikely because some allies and partners, in this case South Korea, are unprepared to treat China as an enemy. Make no mistake: most of Japan's and South Korea's role-taking re-affirmed the U.S.' initial role enactments so that established alliance structures, as well as diplomatic and economic institutions remained intact. No role transformation (such as South Korea abandoning the U.S. and turning towards China) has taken place or appears probable in the foreseeable future. Yet we assert that there are substantial differences in the respective role expectations between the U.S. and both allies, and in between the two allies (see Table 1). 
Table 1. Overview Role-Taking

\begin{tabular}{|c|c|c|c|c|}
\hline $\begin{array}{c}\text { Country I } \\
\text { Dimension }\end{array}$ & Diplomacy & Security & Economy & $\begin{array}{c}\text { Role-making } \\
\text { of the Pivot }\end{array}$ \\
\hline U.S. & Mediator & Constrained balancer & Initiator / Mediator & Ambiguity \\
\hline Japan & (matured) Balancer & Balancer & Troubled reformer & Securitizing \\
\hline South Korea & Constrained trustbuilder & Contested pacifier & Equidistant partner & Moralizing \\
\hline
\end{tabular}

In our view, role theory proved to be a useful tool in identifying key differences between the allies' responses and the resulting social structuration process. First, role theory, through incorporating the process of historical self-identification, helps us to better understand the patterns of positive and negative historical self-identification as a source of current role-taking. Second, because role theory considers external expectations as essential for an actor's own role conception, changes of the "significant others" of a role explain how and why role conflict through diverging or cross-cutting expectations - occur.

A first empirical theme of our analysis is that Japan's response to the Pivot "securitized" the initial U.S. role-taking, i.e. the Abe government has - against the background of a re-evaluation of Japan's history in Northeast Asia - been emphasizing the military pillar, thereby casting China into the role of the competing other. While Japan took on the role of a balancer towards China, substantial doubts about the U.S. commitment and the exclusivity of the U.S.Japan alliance remained. To the extent the Abe government doubted the sincerity or sustainability of the U.S., Japan started to diversify its portfolio of security partners, especially in Southeast and South Asia. Against the background of a parallel securitized interpretation of TPP and ongoing domestic contestation about Japan's economic integration, the Abe administration had to limit its commitments or sought alternative trading schemes.

A second empirical theme is that South Korea's historical self-identification strongly colored its limited direct and indirect security cooperation with Japan, its guarded approach towards China's robust territorial claims and its equidistant positioning between Washington and Beijing in the economic realm. At the same time, President Park's failed Trustpolitik, although sought to overcome historical wrongs through multilateral dialogue, made Seoul much more contingent on significant other's role-interaction, due to ongoing domestic contestations regarding THAAD deployment and North Korean aggression.

A third empirical theme is that gaining followers for its revamped leadership is as important for the U.S. as getting fresh money for weapons systems. 
Importantly, the U.S. itself triggered many of those historic and current selfidentification processes by alter-casting states in unforeseen roles (i.e. burden sharer or economic reformer) or by unsubstantiated own role-taking in terms of resources and commitment, thus provoking doubt about the sincerity of the Pivot's direction and sustainability. As South Korea's foot dragging on THAAD and its AIIB membership makes clear, China remained on the Park administration's mind.

Some difference in the ascription of meaning of state action is always to be expected. As we argue here, in expanding the basic insight of role theory, the sociality of roles, i.e. processes of historical self-identification and the selection of significant others, are essential factors when analyzing emerging security structures. Balancing expectations by others, which may share positive selfidentifications but may also carry along the remembrance of the worst, requires as much attention as counting weapons systems or building shields against swords.

\section{REFERENCES}

Acharya, Amitav. 2011. "Can Asia Lead? Power Ambitions and Global Governance in the Twenty-First Century.” International Affairs 87(4), $851-869$.

Armitage, Richard and Joseph Nye. 2012. "The U.S.-Japan Alliance: Anchoring Stability in Asia." A report of the CSIS Japan Chair. Accessed at http://csis.org/files/publication/120810_Armitage_ USJapanAlliance_Web.pdf (June 15, 2016).

Asia Maritime Transparency Initiative. 2016. "What Countries are Taking Sides after the South China Sea Ruling?" Center for Strategic and International Studies. Accessed at https://amti.csis.org/sides-insouth-china-sea/ (September 2, 2016).

Azizian, Rouben. 2012. "United States and the Asia-Pacific: Balancing Rhetoric and Action." In Rouben Azizian and Artyom Lukin eds., From APEC 2011 to APEC 2012: American and Russian Perspectives on AsiaPacific Security and Cooperation. Honolulu: Asia-Pacific Center for Security Studies, 114-126.

Beneš, Vít and Sebastian Harnisch. 2015. "Role Theory in Symbolic Interactionism: Czech Republic, Germany and the EU." Cooperation and Conflict 50(1), 46-65.

Burgess, Stephen F. 2016. "Rising Bipolarity in the South China Sea: the 
American Rebalance to Asia and China's Expansion.” Contemporary Security Policy 37(1), 111-143.

Callahan, William A. and Elena Barabantseva. 2012. China Orders the World: Normative Soft Power and Foreign Policy. Baltimore: Johns Hopkins University Press.

Cantir, Cristian and Juliet Kaarbo. 2016. Domestic Role Contestation, Foreign Policy, and International Relations. New York: Routledge.

Capistrano, Andrew R. and Shuhei Kurizaki. 2016. “Japan's Changing Defense Posture and Security Relations in East Asia.” The Korean Journal of International Studies 14(1), 77-104.

Carter, Ash. 2015. "Remarks on the Next Phase of the U.S. Rebalance to the Asia-Pacific.” Accessed at http://www.defense.gov/News/Speeches/ Article/60666o (June 15, 2016).

Castro, Renato Cruz De. 2013. “The Obama Administration's Strategic Pivot to Asia: From a Diplomatic to a Strategic Constrainment of an Emergent China?" The Korean Journal of Defense Analysis 25(3), 331-349.

Chadha, Vivek. 2014. "Military Implications of the US Rebalancing Strategy". In S. D. Muni and Vivek Chadha eds., Asian Strategic Review 2014: U.S. Pivot and Asian Security. New Delhi: Institute for Defence Studies \& Analyses, 31-47.

Chan, Steve. 2012. Looking for Balance: China, the United States, and Power Balancing in East Asia. Stanford: Stanford University Press.

Chapman, Andrew. 2016. "Japan's Proactive Pacifism in Action: Supporting International Law and Stability in the South China Sea." New Perspectives in Foreign Policy 9(winter). Accessed at http://csis.org/ files/publication/160104_new_perspectives_issue9.pdf (June 15, 2016).

Christensen, Thomas J. 2015. The China Challenge: Shaping the Choices of a Rising Power. New York: W. W. Norton \& Company, Inc.

Chung, Jae Ho. 2007. Between Ally and Partner: Korea-China Relations and the United States. New York: Columbia University Press.

Clinton, Hillary. 2011. “America's Pacific Century.” Foreign Policy. Accessed at http://foreignpolicy.com/2011/10/11/americas-pacific-century/ (June 15, 2016).

Councilon Foreign Relations. 2016. "Rebalance to Asia Led to Drop in Security Assistance for Southeast Asia.” Accessed at http://www.cfr.org/asiaand-pacific/rebalance-asia/p37516\#!/ (June 15, 2016).

Delury, John. 2015. "The Kishi Effect: A Political Genealogy of Japan-ROK Relations." Asian Perspective 39(3), 441-460. 
Deni, J. R. 2015. "The Real Rebalancing: American Diplomacy and the Tragedy of President Obama's Foreign Policy.” Accessed at http:// www.dtic.mil/cgi-bin/GetTRDoc?Location=U2\&doc=GetTRDoc. pdf\&AD=ADA623799 (June 15, 2016).

De Rougé, Guillaume. 2015. "The Political Economy of the US Rebalance: Revisiting the 'Web of Linkages' between National Security and Economic Prosperity." In Hugo Meijer ed., Origins and Evolution of the US Rebalance toward Asia. New York: Palgrave MacMillan, 107126.

Department of Defense. 2012. "Sustaining US Global Leadership: Priorities for 21st Century Defense.” Accessed at http://www.defense.gov/news/ Defense_Strategic_Guidance.pdf (June 15, 2016). . 2013. "Air Sea Battle.” Accessed at http://www.defense.gov/pubs/ ASB-ConceptImplementation-Summary-May-2013.pdf (June 15, 2016).

Department of State. 2013. "Limits in the Seas." Bureau of Oceans and International Environmental and Scientific Affairs 143. Accessed at http://www.state.gov/documents/organization/234936.pdf. (June 15, 2016).

. 2014. "The U.S.-ASEAN Expanded Economic Engagement (E3) Initiative." Accessed at http://www.state.gov/r/pa/prs/ ps/2013/10/215235 (June 15, 2016).

Dian, Matteo. 2015. "The Pivot to Asia, Air-Sea Battle and contested commons in the Asia Pacific region." The Pacific Review 28(2), 237-257.

Dormandy, Xenia. 2012. "Prepared for Future Threats? US Defence Partnerships in the Asia-Pacific Region." Chatham House Program Report. Accessed athttp://www.chathamhouse.org/sites/files/ chathamhouse/public/Research/Americas/pro612dormandy.pdf (June 15, 2016).

Envall, H. D. P. and Kerri Ng. 2015. "The Okinawa "Effect” in US-Japan Alliance Politics.” Asian Security 11(3), 225-241.

Feigenbaum, Evan A. and Robert A Manning. 2009. "The United States in the New Asia.” Council Special Report 5O. Accessed at http://www.cfr.org/ content/publications/attachments/Asian_Multilateralism_CSR50.pdf (June 15, 2016).

Fergusson, Ian F., Mark A. McMinimy, and Brock R. Williams. 2015. "The Trans-Pacific Partnership (TPP) Negotiations and Issues for Congress." CRS Report for Congress. Accessed at https://www.fas.org/sgp/crs/ row/R42694.pdf (June 15, 2016). 
Finnemore, Martha. 2009. "Legitimacy, Hypocrisy, and the Social Structure of Unipolarity." World Politics 61(1), 58-85.

Foot, Rosemary and Andrew Walter. 2011. China, the United States and Global Order. New York: Cambridge University Press.

Friedberg, Aaron L. 2005. "The Future of U.S.-China Relations: Is Conflict Inevitable?" International Security 30(2), 7-45. . 2011. A Contest for Supremacy: China, America, and the Struggle for Mastery in Asia. New York: W.W. Norton. . 2014. Beyond Air-Sea Battle: The Debate Over U.S. Military Strategy in Asia. New York and London: Routledge.

Friedrichs, Gordon and Sebastian Harnisch. 2016. "Rebalancing Getting Nowhere? The US Pivot to Asia and Its Unintended Consequences." ASIEN 139, 44-74.

Futter, Andrew and Benjamin Zala. 2015. "Coordinating the Arm Swing with the Pivot: Nnuclear Deterrence, Stability, and US Strategy in the AsiaPacific." The Pacific Review 28(3), 367-390.

Gertz, Bill. 2013. The China Threat: How the People's Republic Targets America. Washington, D.C.: Regnery Publishing.

Glaser, Charles L. 2010. Rational Theory of International Politics: The Logic of Competition and Cooperation. Princeton, N.J.: Princeton University Press.

Glosserman, Brad and Scott A. Snyder. 2015. The Japan-South Korea Identity Clash: East Asian Security and the United States. New York: Columbia University Press.

Green, Michael and Matthew P. Goodman. 2016. "After TPP: the Geopolitics of Asia and the Pacific." The Washington Quarterly 38(4), 19-34.

Green, Michael and Nicholas Szechenyi. 2014. "US-Japan Relations: The Sushi Summit." Comparative Connections 14(1), 19-28.

Green, Michael. 2013. "Japan is Back: Unbundling Abe’s Grand Strategy.” Accessed at http://www.lowyinstitute.org/files/green_japan_is_back_ web_o.pdf (June 15, 2016).

Grieco, Joseph M. 2014. "Theories of International Balancing, the Rise of China, and Political Alignments in the Asia Pacific." The Korean Journal of International Studies 12 (Special Edition), 15-48.

Hagström, Linus and Karl Gustafsson. 2015. "Japan and Identity Change: Why it Matters in International Relations." The Pacific Review 28(1), 1-22.

Harnisch, Sebastian, Sebastian Bersick, and Joern-Carsten eds., 2016. China's International Roles Challenging or Supporting International Order?(Role Theory and International Relations). New York: 
Routledge.

Harnisch, Sebastian. 2012. "Conceptualizing in the Minefield: Role Theory and Foreign Policy Learning.” Foreign Policy Analysis 8(1), 47- 71.

Harnisch, Sebastian, Cornelia Frank, and Hanns W Maull. 2011. Role Theory in International Relations: Contemporary Approaches and Analyses. New York: Routledge.

Heath, Timothy R. 2012. "What Does China Want? Discerning the PRC's National Strategy.” Asian Security 8(1), 54-72.

Hermanns, Heike. 2013. "National Role Conceptions in the 'Global Korea' Foreign Policy Strategy.” The Korean Journal of International Studies 11(1), 55-82.

Hoey, Fintan. 2016. “Japan and Extended Nuclear Deterrence: Security and Non-proliferation.” Journal of Strategic Studies 39(4), 484-501.

Holsti, K. J. 1970. "National Role Conceptions in the Study of Foreign Policy." International Studies Quarterly 14(3), 233-309.

Hornbeck, J. F. and William H Cooper. 2010. "Trade Promotion Authority (TPA) and the Role of Congress in Trade Policy." CRS Report for Congress. Accessed at https://www.fas.org/sgp/crs/misc/RL33743.pdf (June 15, 2016).

Hosoya, Yuichi. 2016. “Japan's New Security Legislation: What Does This Mean to East Asian Security?" American Foreign Policy Interests: The Journal of the National Committee on American Foreign Policy 37(56), 296-302.

Hsiung, James C. 2015. "Utility vs. Inadequacy of Realist IR Theory: Assessing China's Rise." International Studies Review 17(1), 132-137.

Huang, David W.F. 2016. Asia Pacific Countries and the US Rebalancing Strategy. New York: Palgrave Macmillan.

Hwang, Jihwan. 2003. "Rethinking the East Asian Balance of Power." World Affairs 166(2), 95-107.

Ikenson, Daniel. 2015. "Trade Promotion Authority and the Trans-Pacific Partnership: What Lies Ahead?" Free Trade Bulletin 61. Accessed at http://www.cato.org/publications/free-trade-bulletin/tradepromotion-authority-trans-pacific-partnership-what-lies-ahead (June 15, 2016).

Ilias, Shayerah, Ian F. Fergusson, Wayne M. Morrison, and M. Angeles Villarreal. 2011. "Boosting U.S. Exports: Selected Issues for Congress." CRS Report for Congress. Accessed at https://www.fas.org/sgp/crs/ misc/R41929.pdf (June 15, 2016).

Izumi, Hajime. 2001. "Remembering and Forgetting: Japan-Korea 
Dimensions." In Gerrit W. Gong ed., Memory and History in East and Southeast Asia: Issues of Identity in International Relations. Washington, D.C.: The CSIS Press, 86-112.

Jackson, Van. 2016. "Red Teaming the Rebalance: The Theory and Risks of US Asia Strategy.” Journal of Strategic Studies 39(3), 365-388.

Jensen, Benjamin M. and Eric Y Shibuya. 2015. "The Military Balance as Retcon.” In Hugo Meijer ed., Origins and Evolution of the US Rebalance toward Asia. New York: Palgrave MacMillan, 81-106.

Jimbo, Ken. 2015. "US Rebalancing to the Asia-Pacific: A Japanese Perspective." In William T. Tow. and Douglas Stuart eds., The New US Strategy towards Asia: Adapting to the American Pivot. London, New York: Routledge, 77-89.

John, Jojin V. 2014. "Becoming and Being a Middle Power: Exploring a New Dimension of South Korea's Foreign Policy." China Report 50(4), 325341.

Johnston, Alastair Iain. 2003. "Is China a Status Quo Power?” International Security 27(4), 5-56.

Kang, David. 2008. China Rising: Peace, Power, and Order in East Asia. New York: Columbia University Press.

Kang, David and Jiun Bang. 2015. "Japan-Korea Relations: Sorry Seems the Hardest Word (unless you're a CEO).” Comparative Connections: A Triannual E-Journal on East Asian Bilateral Relations 17(2), 133-146.

Kawai, Masahiro and Ganeshan Wignaraja. 2010. "Asian FTAs: Trends, Prospects, and Challenges." ADB Economics Working Paper Series 226. Accessed at http://www.un.org/esa/ffd/wp-content/ uploads/2010/11/20101115_ADB_WPs.pdf (June 15, 2016).

Keck, Zachary. 2015. "China's Worst Nightmare? Japan may Sell India Six Stealth Submarines." Accessed at http://nationalinterest.org/blog/ chinas-worst-nightmare-japan-may-sell-india-six-stealth-12149 (June 15, 2016).

Khan, Shamshad. 2014. "Deconstructing "Tokyo Declaration" 2014: Takeaways from Indian Prime Minister's Japan visit." Issue Brief. Accessed at http://www.icwa.in/pdfs/IB/2014/ DeconstructingTokyoDeclaration2014.pdf (June 15, 2016).

Kim, Changsu. 2015a. "South Korea's Adaptation to the US Pivot to Asia."

In William T. Tow and Douglas Stuart eds., The New US Strategy Towards Asia: Adapting to the American Pivot. New York: Routledge, 90-101.

Kim, Ji Young. 2015b. "Rethinking the Role of Identity Factors: The History 
Problem and the Japan-South Korea Security Relationship in the PostCold War Period." International Relations of the Asia-Pacific 15(3), 477-503.

Kim, Samuel S. 2006. The Two Koreas and the Great Powers. New York: Cambridge University Press.

Klingner, B. 2016. "Japanese Defense Reform Supports Allied Security Objectives." The Heritage Foundation. Accessed at http://www. heritage.org/research/reports/2016/o1/japanese-defense-reformsupports-allied-security-objectives (June 15, 2016).

Ko, Sung-Bin. 2006. "South Korea's Search for an Independent Foreign Policy." Journal of Contemporary Asia 36(2), 258-273.

Kugler, Jacek. 2006. "The Asian Ascent: Opportunity for Peace or Precondition for War?" International Studies Perspectives 7(1), 36-42.

Lee, Chung. 2016. Fault Lines in a Rising Asia. Washington, D.C.: Carnegie Endowment for International Peace.

Lee, John. 2015. “Tokyo Ascending: Abe's New Defense Strategy.” Accessed at http://www.worldaffairsjournal.org/article/tokyo-ascending-abe'snew-defense-strategy (June 15, 2016).

Lee, Shin-wha. 2011. "The East Asia Summit and the Difficulty of Establishing a Security Regime in Northeast Asia: Current Issues in U.S.-ROK Relations." Other Report. Accessed at http://www.cfr.org/south-korea/ east-asia-summit-difficulty-establishing-security-regime-northeastasia/p26543 (June 15, 2016).

Legro, Jeffrey W. 2007. "What China Will Want: The Future Intentions of a Rising Power." Perspectives on Politics 5(3), 515-534.

Le Mière, Christian. 2013. "Rebalancing the Burden in East Asia." Survival: Global Politics and Strategy 55(2), 31-41.

Levy, J.S. 2008. "Power-Transition Theory and the Rise of China." In R. S. Ross and Z. Feng eds., China's Ascent: Power, Security, and the Future of International Politics. Ithaca, NY and London: Cornell University Press, 11-33.

Lieberthal, Kenneth and Wang Jisi. 2012. "Addressing U.S.-China Strategic Distrust. " John L. Thorton China Center Monograph Series 4. Accessed at http://www.brookings.edu/ /media/research/files/ papers/2012/3/30\%20us\%20china\%2olieberthal/o330_china_ lieberthal.pdf (June 15, 2016).

Liff, Adam and G. John Ikenberry. 2014. "Racing toward Tragedy? China's Rise, Military Competition in the Asia Pacific, and the Security Dilemma." International Security 39(2), 52-91. 
Liff, Adam P. 2014. "Whither the Balancers? Reconsidering Methods and Metrics in Contemporary Security Studies and Secondary State Military Balancing Responses to China's Rise." Security Studies 25(3), 420-459. . 2015. "Japan's Defense Policy: Abe the Evolutionary." The Washington Quarterly 38(2), 79-99.

Lim, C.L., Deborah K. Elms and Patrick Low. 2012. The Transpacific partnership. A Quest for a Twenty-First Century Trade Agreement. New York: Cambridge University Press.

Lindley, Dan. 2007. Promoting Peace through Information: Transparency as a Tool of Security Regimes. Princeton, N.J.: Princeton University Press.

Manicom, James 2014. Bridging Troubled Waters: China, Japan, and Maritime Order in the East China Sea. Washington, D.C.: Georgetown University Press.

Manyin, Mark E., Emma Chanlett-Avery, Mary Beth D. Nikitin, Ian E. Rinehart, and Brock R Williams. 2015. "U.S.-South Korea Relations." CRS Report for Congress. Accessed athttps://www.fas.org/sgp/crs/ row/R41481.pdf (June 15, 2016).

Manyin, Mark E., Stephen Daggett, Ben Dolven, Susan V. Lawrence, Michael F. Martin, Ronald O'Rourke, and Bruce Vaughn. 2012. "Pivot to the Pacific? The Obama Administration's "Rebalancing" toward Asia." CRS Report for Congress. Accessed at https://www.fas.org/sgp/crs/natsec/ R42448.pdf (June 15, 2016).

Manyin, Mark E., Michael John Garcia, and Wayne M. Morrison. 2009. "U.S. Accession to the Association of Southeast Asian Nations' Treaty of Amity and Cooperation (TAC)." CRS Report for Congress. Accessed at http:// fpc.state.gov/documents/organization/124064.pdf (June 15, 2016).

Martin, Michael F. 2012. "The Asia-Pacific Economic Cooperation (APEC) Meetings in Vladivostok, Russia: Postscript." CRS Report for Congress. Accessed at https://www.fas.org/sgp/crs/row/R42842.pdf (June 15, 2016).

Maslow, Sebastian. 2016. "China and Japan: Partner, Rival, and Enemy?” In Sebastian Harnisch, Sebastian Bersick, and Jorn-Carsten Gottwald eds., China's International Roles. Challenging or Supporting International Order? New York: Routledge.

McDevitt, Michael. 2016. "The South China Sea: Island Building and Evolving U.S. Policy." American Foreign Policy Interests: The Journal of the National Committee on American Foreign Policy 37(5-6), 253-263

McLeary, Paul and Bradley Peniston. 2014. "Analysis: Congress Reworks 10 Percent of DoD Procurement Budget." Defense News. Accessed 
at http://www.defensenews.com/story/defense/international/ americas/2014/12/15/analysis-congress-reworks-10-percent-of-dodprocurement-budget/20438717/ (June 15, 2016).

Mearsheimer, John. 2006. “China's Unpeaceful Rise.” Current History 105, 160-162.

Mehta, Aaron. 2015. "Carter Announces \$425M in Pacific Partnership Funding." Defense News. Accessed at http://www.defensenews. com/story/defense/2015/05/30/carter-announces-425m-in-pacificpartnership-funding/28206541/ (June 15, 2016).

Meijer, Hugo. 2015. Origins and Evolution of the US Rebalance toward Asia. New York: Palgrave MacMillan.

Ministry of Defense. 2013. "National Defense Program Guidelines for FY 2014 and beyond." Accessed at www.mod.go.jp/j/approach/agenda/ guideline/2014/pdf/20131217_e2.pdf (June 15, 2016).

Ministry of Foreign Affairs. 2014. "Regarding Discussions toward Improving Japan-China Relations. Accessed at http://www.mofa.go.jp/a_o/c_m1/ cn/page4e_ooo15o.html (June 15, 2016).

Mitzen, Jennifer. 2006. "Ontological Security in World Politics: State Identity and the Security Dilemma." European Journal of International Relations 12(3), 341-370.

Moon, Katherine H. S. 2013. Protesting America: Democracy and US-Korea Relations. Berkeley: University of California Press.

Mulgan, Aurelia George. 2016. "Securitizing the TPP in Japan: Policymaking Structure and Discourse.” Asia Policy 22(July), 193-221.

Murray, Hiebert and Liam Hanlon. 2012. "ASEAN and Partners Launch Regional Comprehensive Economic Partnership.” Accessed at http://csis.org/publication/asean-and-partners-launch-regionalcomprehensive-economic-partnership (June 15, 2016).

Nakanishi, Hiroshi. 2015. "Reorienting Japan? Security Transformation Under the Second Abe Cabinet." Asian Perspective 39(3), 405-422.

Nakano, Ryoko. 2015. "The Sino-Japanese Territorial Dispute and Threat Perception in Power Transition.” The Pacific Review 29(2), 165-186.

Nicolas, Francoise. 2007. "Korea's Regional Economic Strategy in Response to the Rise of China." In Francoise Nicolas ed., Korea in the New Asia: East Asian Integration and the China Factor. London \& New York: Routledge, 27-51.

Obama, Barack. 2011. "U.S. President B. Obama's Address to the Australian Parliament." Accessed at http://www.smh.com.au/national/text-ofobamas-speech-to-parliament-20111117-1nkcw.html (June 15, 2016). 
O’Neil, Andrew. 2015. "South Korea as a Middle Power: Global Ambitions and Looming Challenges.” In Scott Snyder ed., Middle Power Korea: Contribution to the Global Agenda. New York: Council on Foreign Relations, 75-89.

Palmer, Anna and John Bresnahan. 2015. "Trade Pact may not come up in House until after 2016 Election.” Politico. Accessed at http://www. politico.com/story/2015/10/trade-trans-pacific-partnership-214807 (June 15, 2016).

Parameswaran, Prashanth. 2014. "Explaining US Strategic Partnerships in the Asia-Pacific Region: Origins, Developments and Prospects." Contemporary Southeast Asia: A Journal of International Affairs and Strategic Affairs 26(2), 262-289.

Park, Cheol Hee. 2011. "Getting away or Getting in: U.S. Strategic Options in the Historical Controversy between its Allies.” In Gilbert Rozman ed., U.S. Leadership, History, and Bilateral Relations in Northeast Asia. Princeton University: Cambridge University Press, 124-142.

Park, Geun-hye. 2011. "A New Kind of Korea." Foreign Affairs 90(5), 13-18. . 2016. "Commemorative Address by President Park Geun-hye on the 71st Anniversary of Liberation." Accessed at http://english1. president.go.kr/util/search.php?srh\%5Btext\%5D=Commemor ative + Address + by + President + Park + Geun-hye + on + the $+71 \mathrm{st}+\mathrm{A}$ nniversary+of+Liberation\&srh\%5Btype\%5 D=2\&srh\%5Bview_ mode\%5D=detail\&srh\%5Bseq\%5D=16994(September 3, 2016).

Paul, Michael. 2015. "Die amerikanische Schwerpunktverlagerung nach Asien: Die militärische Dimension.” SWP-Studie (S5). Accessed at http:// www.swp-berlin.org/fileadmin/contents/products/studien/2015_ So5_pau.pdf (June 15, 2016).

Pollack, Jonathan E. 2016. "South Korea's THAAD Decision: Neither a Surprise nor a Provocation.” Brookings Blog. Accessed at https://www. brookings.edu/blog/order-from-chaos/2016/o7/o8/south-koreasthaad-decision-neither-a-surprise-nor-a-provocation/ (July 8, 2016).

Rice, Susan E. 2013. “America's Future in Asia: Remarks as Prepared for Delivery by National Security Advisor Susan E. Rice.” Accessed at https://www.whitehouse.gov/the-press-office/2013/11/21/remarksprepared-delivery-national-security-advisor-susan-e-rice (June 15, 2016).

Rinehart, Ian E., Steven A. Hildreth, and Susan V. Lawrence. 2015. "Ballistic Missile Defense in the Asia-Pacific Region: Cooperation and Opposition.” CRS Report for Congress. Accessed at https://www.fas. 
org/sgp/crs/nuke/R43116.pdf (September 2, 2016).

Rocher, Sophie Boisseau du and Francoise Nicolas. 2007. "Korea in the New Asia." In Francoise Nicolas ed., Korea in the New Asia: East Asian Integration and the China Factor. London \& New York: Routledge, 1-10.

Ross, Robert and Feng Zhu. 2008. China's Ascent: Power, Security and the Future of International Politics. Ithaca: Cornell University Press.

Rozman, Gilbert. 2011. U.S. Leadership, History, and Bilateral Relations in Northeast Asia. Princeton University: Cambridge University Press.

Sakaki, Alexandra. 2015. "Japan's Security Policy: A Shift in Direction under Abe?” SWP Research Paper. Accessed at http://www.swp-berlin.org/ fileadmin/contents/products/research_papers/2015_RPo2_skk.pdf (June 15, 2016).

Saltzman, Ilai Z. 2015. "Growing Pains: Neoclassical Realism and Japan's Security Policy Emancipation.” Contemporary Security Policy 36(3), 498-527.

Schneider, Howard. 2013. "For controversial trade pact, fire from the left, the right and WikiLeaks." Washington Post. Accessed at http://www. washingtonpost.com/business/economy/for-controversial-trade-pactfire-from-the-left-the-right-and-wikileaks/2013/11/13/118e5d28-4c9a11e3-ac54-aa84301ced81_story.html (June 15, 2016).

Selden, Mark. 2011. "Small Islets, Enduring Conflict: Dokdo, Korea-Japan Colonial Legacy and the United States." The Asia-Pacific Journal 9(17-2), 1-13.

Sheen, Seong-ho. 2014. "Dilemma of South Korea's Trust Diplomacy and Unification Policy." International Journal of Korean Unification Studies 23(2), 97-122.

Shorrock, Tim. 2015. "Could Japan Become America's New Proxy Army?" Accessed at http://www.thenation.com/article/could-japan-becomeamericas-new-proxy-army/ (June 15, 2016).

Silove, Nina. 2016. "The Pivot before the Pivot: U.S. Strategy to Preserve the Power Balance in Asia." International Security 40(4), 45-88.

Singh, Bhubhindar 2015. "The Development of Japanese Security Policy: A Long-Term Defensive Strategy.” Asia Policy 19(1), 49-64.

Smith, Sheila and Charles McClean. 2015. "US-Japan Relations: History and Other Alliance Constraints." Comparative Connections: A Triannual E-Journal on East Asian Bilateral Relations 17(2), 17-26.

Smith, Sheila A. 2015. Intimate Rivals: Japanese Domestic Politics and a Rising China. New York: Columbia University Press. 
Snyder, Scott. 2016. "China's Limited Retaliation Options against the THAAD Deployment in South Korea." CFR Blog 'Asia Unbound'. Accessed at http://blogs.cfr.org/asia/2016/o8/o8/chinas-limited-retaliationoptions-against-the-thaad-deployment-in-south-korea/ (August 8, 2016).

Snyder, Scott and See-won Byun. 2015. "China-Korea Relations: Prospects for a Strategic Partnership?” Comparative Connections: A Triannual E-Journal on East Asian Bilateral Relations 17(2), 101-114.

Son, Key-Young. 2006. South Korean Engagement Policies and North Korea: Identities, Norms and the Sunshine Policy. New York: Routledge.

Spegele, Brian. 2011. "Beijing Warns Against Sea Meddling." The Wall Street Journal. Accessed at http://www.wsj.com/news/articles/SB100014240 52702304665904576385234220024592 (June 15, 2016).

Suzuki, Shogo. 2015. “The Rise of the Chinese 'Other' in Japan's Construction of Identity: Is China a Focal Point of Japanese Nationalism.” The Pacific Review 28(1), 95-116.

Swaine, Michael D. 2012. "Chinese Leadership and Elite Responses to the U.S. Pacific Pivot.” China Leadership Monitor 38. Accessed at http:// carnegieendowment.org/files/CLM38MS.pdf (June 15, 2016).

Tan, See Seng. 2015. "Change and Continuity in America's Asia Pivot: US Engagement with Multilateralism in the Asia Pacific." In Hugo Meijer ed., Origins and Evolution of the US Rebalance toward Asia. New York: Palgrave MacMillan, 55-80.

Thies, Cameron G. 2010. "Role Theory and Foreign Policy." In Robert A. Denemark ed., The International Studies Encyclopedia. Oxford: WileyBlackwell, Vol. X, 6335-6356. . 2013. The United States, Israel, and the Search for International Order: Socializing States. New York: Routledge.

Togo, Kazuhiko. 2011. "Japan-South Korea Relations and the Role of the United States on History.” In Gilbert Rozman ed., U.S. Leadership, History, and Bilateral Relations in Northeast Asia. Princeton University: Cambridge University Press, 97-123.

Tow, William T. 2013. "The United States and Asia in 2013: From Primacy to Marginalization?” Asian Survey 54(1), 12-21.

Tow, William T. and Douglas Stuart. 2015. The New US Strategy towards Asia: Adapting to the American Pivot. New York: Routledge.

Van Tol, Jan and Andrew Krepinevich. 2011. "Air-Sea Battle a Point-ofDeparture Operational Concept, Washington.” Accessed at http:// csbaonline.org/publications/2010/05/airsea-battle-concept/ (June 15, 
2016).

Walker, Stephen G. 1987. Role Theory and Foreign Policy Analysis. Durham: Duke University Press.

White House. 2011. "Remarks by President Obama to the Australian Parliament." Accessed at https://www.whitehouse.gov/the-pressoffice/2011/11/17/remarks-president-obama-australian-parliament (June 15, 2016).

. 2014. "White House Fact Sheet: 2nd ASEAN-U.S. Summit." Accessed at http://www.whitehouse.gov/the-press-office/2014/11/13/fact-sheet2nd-asean-us-summit (June 15, 2016).

. 2014. "Fiscal Year 2015 Budget Request." Accessed at http://www. gpo.gov/fdsys/pkg/BUDGET-2015-BUD/pdf/BUDGET-2015-BUD.pdf (June 15, 2016).

. 2015a. "Fiscal Year 2016 Budget of the U.S. Government." Accessed at http://www.whitehouse.gov/sites/default/files/omb/budget/fy2016/ assets/budget.pdf (June 15, 2016).

. 2015b. "National Security Strategy." Accessed at https://www. whitehouse.gov/sites/default/files/docs/2015_national_security_ strategy.pdf (June 15, 2016).

. 2016a. "Remarks by President Obama at Opening Session of the U.S.ASEAN Summit." Accessed at https://www.whitehouse.gov/the-pressoffice/2016/02/15/remarks-president-obama-opening-session-usasean-summit (June 15, 2016).

. 2016b. "Joint Statement of the U.S.-ASEAN Special Leaders' Summit:

Sunnylands Declaration.” Accessed at https://www.whitehouse.gov/ the-press-office/2016/02/16/joint-statement-us-asean-special-leaderssummit-sunnylands-declaration (June 15, 2016).

. 2016c. "Remarks by President Obama, President Park Geun-Hye of the Republic of Korea, and Prime Minister Shinzo Abe of Japan After Trilateral Meeting." Accessed at https://www.whitehouse.gov/thepress-office/2016/o3/31/remarks-president-obama-president-parkgeun-hye-republic-korea-and-prime (September 2, 2016).

Wiegand, Krista E. 2015. "The South Korean-Japanese Security Relationship and the Dokdo/Takeshima Islets Dispute." The Pacific Review 28(3), 347-366.

Wish, Naomi Bailin. 1980. "Foreign Policy Makers and Their National Role Conceptions.” International Studies Quarterly 24(4), 532-554.

Wood, Dakota L. 2015. "2016 Index of U.S. Military Strength: Assessing America's Ability to Provide for the Common Defense.” Accessed at 
http://index.heritage.org/military/2016/ (June 15, 2016).

Yamaguchi, Noburo. 2016. "The Sino-Japanese Relationship and Its Implications for Regional Security in East Asia." American Foreign Policy Interests: The Journal of the National Committee on American Foreign Policy 37(5-6), 288-295.

Ye, Min. 2015. "China and Competing Cooperation in Asia-Pacific: TPP, RCEP, and the New Silk Road." Asian Security 11(3) 206-224.

Yee, Herbert. 2011. China's Rise: Threat or Opportunity? London: Routledge. Zhang, Feng. 2014. "How Hierarchic was the Historical East Asian System?" International Politics 51(1), 1-22. 